\title{
UJI DISTRIBUSI SEMPROTAN SPRAYER PESTISIDA DENGAN PATTERNATOR BERBASIS WATER LEVEL DETECTOR
}

\section{TEST OF SPRAYER DROPLET DISTRIBUTION USING WATER LEVEL DETECTOR-BASED PATTERNATOR}

\author{
Agus Dharmawan ${ }^{1,2, 凶}$, Siswoyo Soekarno ${ }^{2}$ \\ ${ }^{1}$ Laboratorium Rekayasa Alat dan Mesin Pertanian, Fakultas Teknologi Pertanian, Universitas Jember \\ ${ }^{2}$ Program Studi Teknik Pertanian, Fakultas Teknologi Pertanian, Universitas Jember \\ ${ }^{\square}$ Komunikasi Penulis, email: agusd@unej.ac.id \\ DOI:http://dx.doi.org/10.23960/jtep-l.v9i2.85-95 \\ Naskah ini diterima pada 20 Maret 2020; revisi pada 2 Juni 2020; \\ disetujui untuk dipublikasikan pada 5 Juni 2020
}

\begin{abstract}
The research aimed to examine droplet distribution using a knapsack sprayer with a water level detector-based patternator. The tests consist of measuring spraying discharge, effective spray wide and height, droplet distribution patterns and areas, and traveling speed. The sensor calibration showed that the system read the liquid volume in the container with $R^{2}=0.99$ at a linear curve: $y=2.572+2.502 x$. The spray discharge was $0.033 \mathrm{~L} / \mathrm{s}$. The optimal spray was at $60 \mathrm{~cm}$-nozzle height with effective spray wide and height were $0.64 \mathrm{~m}$ and 0.344 , respectively. The spray distribution pattern illustrated that nozzle height affected droplet areas. The traveling speed due to nozzle height at 40 to $70 \mathrm{~cm}$ was 0.29 to $0.58 \mathrm{~m} / \mathrm{s}$, and had a line-up tendency, whereas spraying capacity was declined 1298 to $562 \mathrm{~L} / \mathrm{Ha}$.
\end{abstract}

Keywords: patternator, sprayer, spray distribution, water level detector

\begin{abstract}
ABSTRAK
Tujuan penelitian ini adalah untuk menguji distribusi droplet sprayer pestisida tipe gendong menggunakan paternator berbasis water level detector. Pengujian terdiri atas pengukuran debit semprotan, lebar dan tinggi penyemprotan efektif, pola dan luas distribusi semprotan, dan kecepatan kerja penyemprotan di lapangan. Hasil kalibrasi sensor menunjukkan bahwa perangkat dapat membaca volume semtoran pada container denga nilai korelasi $\mathrm{R}^{2}=0,99$ pada kurva linier $y=2,572+2,502 x$. Debit penyemprotan sprayer menunjukkan $0,033 \mathrm{~L} / \mathrm{det}$. Penyemprotan optimal sprayer berada pada tinggi semprot $60 \mathrm{~cm}$ dengan lebar penyemprotan efektif $0.64 \mathrm{~m}$ dan tinggi penyemprotan efektif 0,344 m. Pola distribusi penyemprotan menunjukkan bertambahnya tinggi nosel semprot mempengaruhi luas penyemprotan. Kecepatan kerja akibat perbedaan tinggi penyemprotan dari 40 ke $70 \mathrm{~cm}$ cenderung naik dengan nilai $0,29 \mathrm{~m} / \mathrm{s}$ ke $0,58 \mathrm{~m} / \mathrm{s}$, sedangkan volume aplikasi penyemprotan menurun pada nilai $1298 \mathrm{~L} /$ ha ke $562 \mathrm{~L} / \mathrm{ha}$.
\end{abstract}

Kata Kunci: distribusi semprotan, patternator, sprayer, water level detector

\section{PENDAHULUAN}

Upaya meningkatkan produktivitas pertanian menggunakan pestisida kimia dan alami merupakan cara yang menurut petani paling efektif dalam mengendalikan organisme dan penyakit tanaman (Budi, 2009). Penggunaan pestisida dipilih oleh petani karena harganya yang terjangkau, mudah pengaplikasian dan dapat digunakan dalam area yang luas. Oleh karena masif nya penggunaan pestisida oleh petani, sampai dengan tahun 2016 terdapat 3.930 jumlah pestisida dengan nama dagang yang terdaftar pada Dirjen Prasarana dan Sarana Pertanian Kementerian Pertanian (KEMENTAN, 2016). Pestisida yang beredar di masyarakat dapat berupa cairan emulsi, butiran (granulars), debu (dust), tepung (powder), minyak (oil), dan fumigant (Sudarmo, 1991). 
Budidaya tanaman untuk mengendalikan organisme pengganggu tanaman (OPT) umumnya menggunakan pestisida berbentuk cair dan tepung (Guntur et al, 2016). Pemberian pestisida cair pada tanaman menggunakan alat penyemprot (sprayer). Sprayer berfungsi untuk memecah cairan atau larutan menjadi butiranbutiran dan mendistribusikannya secara merata ke permukaan tanaman yang dilindungi (Yuwana, 2014). Penyemprotan sprayer tidak hanya dipengaruhi oleh debit penyeprotan dari nosel, namun dari banyak faktor seperti distribusi aliran/pola semprotan, arah penyemprotan, pengaruh udara, dan dinamika droplet (Zhai et al., 2015). Pada proses penyemprotan sprayer dibutuhkan informasi mengenai unjuk kinerja alat semprot (sprayer) agar penyemprotan lebih efektif dan efisien saat pengaplikasian pada tanaman.

Banyak petani masih percaya bahwa penyemprotan dengan volume dan tekanan tinggi dapat memastikan tanaman terproteksi dengan baik (Forque et al., 2012). Pengujian kinerja penyemprotan sprayer dilakukan untuk menghindari pemborosan penggunaan pestisida. Penggunaan pestisida dengan volume tinggi dan interval aplikasi penyemprotan yang pendek berakibat pada meningkatnya biaya produksi usaha tani, meningkatkan pencemaran lingkungan, mempercepat terjadinya resistensi OPT, dan kematian musuh-musuh alami (Budi, 2009). Keberhasilan aplikasi pestisida menggunakan sprayer diukur dengan tingkat pengendalian hama yang secara ekonomi dapat diterima dengan dampak terhadap lingkungan yang kecil (Prabaningrum, 2017). Oleh sebab itu, pengujian sprayer harus mampu memberi informasi debit keluaran cairan dan distribusi penyemprotan (Smith et al., 1994).

Patternator merupakan salah satu peralatan yang digunakan untuk pengujian penyemprotan sprayer. Pada prinsipnya, patternator ini berfungsi untuk mengalirkan air butiran halus (droplet) dari mulut nosel ke botol-botol penampung (BSNI, 2008). Patternator yang sering digunakan untuk pengujian sprayer adalah patternator konvensional. Patternator konvensional terdiri dari alur-alur yang miring yang mengalirkan cairan ke botol-botol penampung. Patternator ini dapat menentukan sudut penyemprotan, lebar dan tinggi penyemprotan efektif.

Penggunaan patternator konvensional (BSNI, 2008) pada pengujian penyemprotan sprayer tidak dapat menunjukkan pola distibusi penyemprotan nossel pada luas area penyemprotan, sehingga digunakan grid patternator. Volume droplet pada grid container diukur secara otomatis menggunakan water level detector dengan pembacaan dari sensor ultrasonik. Sensor ultrasonik mendeteksi jarak obyek dengan cara memancarkan gelombang ultrasonik (Permana et al., 2015). Sinyal kemudian dipantulkan kembali dan diterima oleh receiver (Andayani et al., 2016). Sensor ultrasonik pada water level detector dikalibrasi sehingga dapat dijadikan alat pembaca volume hasil penyemprotan yang tertampung pada grid container. Tujuan penelitian ini untuk melakukan pengujian distribusi droplet penyemprotan sprayer yang terdiri atas pengukuran debit semprotan, lebar dan tinggi penyemprotan efektif, pola dan luas distribusi semprotan, dan kecepatan kerja penyemprotan. Pengujian droplet penyemprotan sprayer perlu dilakukan untuk mengatur jumlah dan kebutuhan cairan pestisida yang akan diaplikasikan pada tanaman. Kalibrasi ini juga dapat memastikan ketepatan penyemprotan cairan pestisida pada tanaman (Zhai et al., 2015) sehingga dapat mengendalikan dan mengurangi residu pestisida terbuang pada lingkungan.

\section{BAHAN DAN METODA}

Perancangan patternator dan pengujian distribusi droplet penyemptoran pestisida (debit semprotan, lebar dan tinggi penyemprotan efektif, pola dan luas distribusi semprotan) dilakukan di Laboratorium Rekayasa Alat dan Mesin Pertanian, perancangan rangkaian dan kalibrasi water level detector dilakukan di Laboratorium Instrumentasi Pertanian, dan pengujian lapangan (kecepatan kerja penyemprotan) dilakukan di lahan percobaan Jurusan Teknik Pertanian, Fakultas Teknologi Pertanian, Universitas Jember. Kegiatan penelitian dilaksanakan pada tanggal 01 Oktober 2019 sampai 10 Desember 2019. 
Peralatan yang digunakan dalam perancangan patternator antara lain las listrik, gerinda potong, ragum, palu, mistar baja, spidol, jangka sorong, tang, cutter, dan cutter akrilik. Sedangkan bahan habis pakai yang digunakan terdiri atas pipa besi kotak dan besi siku (40 $440 \times 2 \mathrm{~mm})$, mata gerinda potong, elektroda las, atap fiber gelombang transparan, mika akrilik (tebal 2 $\mathrm{mm}$ ), lem G, dan lem kaca silikon. Peralatan dan bahan yang digunakan pada perancangan water level detector antara lain sensor HC-SR04, IC regulator, Board Arduino, baterai 9V, LCD $16 \times 2$, kawat timah (solder), konektor male-to-female, dan Avometer. Peralatan pengujian penyemprotan sprayer terdiri atas satu unit sprayer gendong semi otomatis (knapsack sprayer) dengan nosel empat lubang, gelas ukur $5 \mathrm{~mL}, 50 \mathrm{~mL}, 100 \mathrm{~mL}$ dan $1000 \mathrm{~mL}$, stopwatch, dan rollmeter. Sedangkan cairan yang digunakan pada penelitian ini adalah air bertemperatur 25,5 ${ }^{0} \mathrm{C}$ (densitas, $\rho=996,9 \mathrm{~kg} / \mathrm{m}^{3}$; viskositas, $\mu=$ $0,882 \times 10^{-3} \mathrm{~kg} / \mathrm{m} . \mathrm{s}$; (Cengel dan Cimbala, 2014)).

\subsection{Perancangan patternator}

Perancangan patternator, Gambar 1, terdiri atas tiga komponen utama:

\section{a. Kerangkan utama}

Kerangka utama berfungsi sebagai penopang 2 (dua) jenis patternator, yaitu patternator konvensional (bagian atas) dan grid patternator (bagian bawah), serta tempat berdirinya penyangga nosel semprot. Penyangga nosel dilengkapi lubang pengait dan skala sebagai pengatur ketinggian penyemprotan terhadap permukaan patternator.

\section{b. Patternator konvensional}

Patternator konvensional berfungsi dalam pengujian sudut penyemprotan, lebar penyemprotan efektif dan tinggi penyemprotan efektif. Patternator ini terbuat dari atap fiber gelombang transparan berukuran $2 \times 1,68 \mathrm{~m}$. Droplet cairan pada ketinggian (yang sudah ditetapkan) disemprotkan pada patternator yang terdapat 21 alur aliran air. Akibat kemiringan $20^{\circ}$ cairan mengalir turun dan tertampung pada botol penampung berukuran $54 \times 50 \times 120 \mathrm{~mm}$.

\section{c. Grid Patternator}

Grid Patternator digunakan dalam pengujian pola distribusi dan luas permukaan penyemprotan sprayer. Patternator ini terbuat dari mika akrilik transparan dengan ketebalan 2 $\mathrm{mm}$. Pada grid patternator, droplet cairan yang tersemprot tertampung pada grid container. Grid container berjumlah 1024 dan berukuran $50 \times$ $50 \times 60 \mathrm{~mm}$.

\subsection{Perancangan water level detector}

Perangkat yang diterapkan untuk pengukuran volume cairan yang tertampung pada grid dilakukan secara otomatis menggunakan sensor ultasonik. Sistem pengukuran yang telah dibuat, Gambar 2, berupa perangkat keras yang terdiri dari LCD $6 \times 2$, ArduinoUNO, dan sensor ultrasonik. Sensor ultrasonik mendeteksi jarak permukaan air dengan sensor. Sensor ultrasonik digunakan untuk mendeteksi kedalaman 0 - 100 $\mathrm{mm}$. Kemudian data hasil pembacaan diolah oleh Arduino UNO dan ditampilkan pada LCD $16 \times 2$ dalam bentuk panjang dengan satuan milimeter. Rangkaian Arduino juga telah dilengkapi dengan IC regulator dan Power Supply.
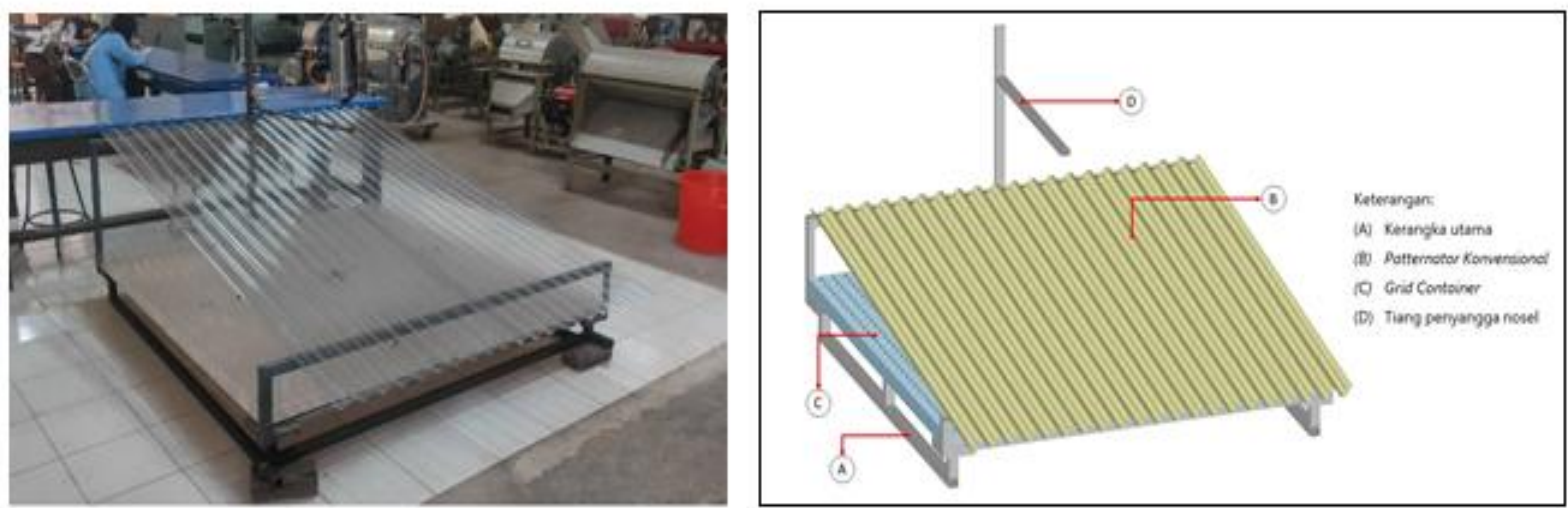

Gambar 1. Desain Konstruksi Patternator 


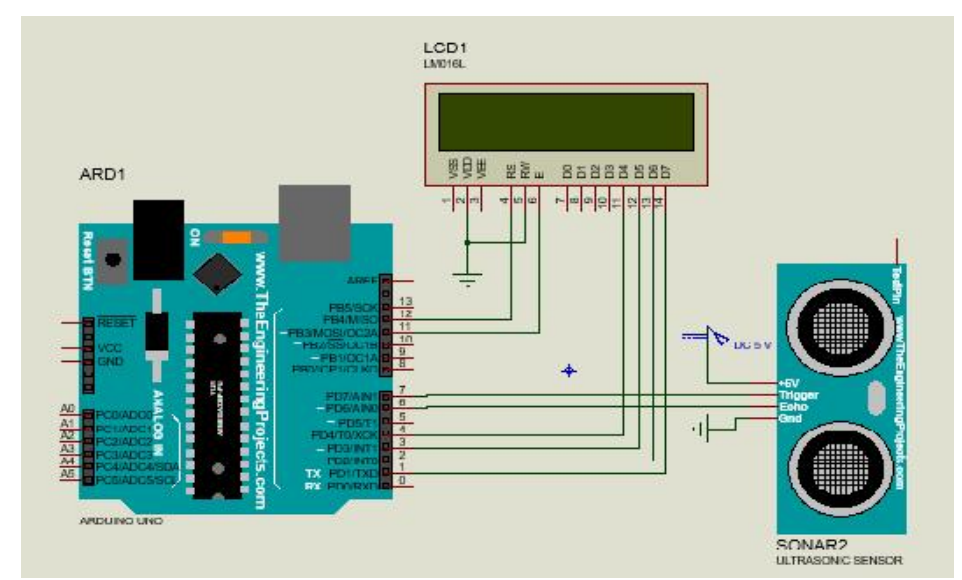

Gambar 2. Rangkaian Elektronika Water Level Detector

\subsection{Kalibrasi water level detector}

Sensor pendeteksi ketinggian muka air merupakan komponen yang digunakan untuk pembacaan volume cairan hasil semprotan yang tertampung pada grid container. Volume cairan semprot dihitung dari pengukuran tinggi cairan dan perhitungan penampang wadah (Zhai et al., 2015). Dalam proses kalibrasi ini, volume air yang akan dibaca pada grid container dihitung penampang grid container dan tinggi muka air. Luas penampang grid container $(50 \times 50 \mathrm{~mm})$ menjadi konstanta tetap sedangkan tinggi muka air berubah-ubah dan meningkat/bertambah secara bertahap dan terukur. Air pembacaan kemudian dicatat dan ditabulasi volumenya, selanjutnya dibaca oleh sensor ultrasonik HCSR04.

Dari volume air yang terbaca oleh gelas ukur dan sensor ultrasonik, kedua data tersebut kemudian dibentuk grafik scatter plot. Volume air pada gelas ukur sebagai variabel $Y$ dan tinggi muka air yang terbaca pada sensor ultrasonic sebagai variabel $X$, lalu dibuat persamaan regresi linear. Persamaan tersebut selanjutnya digunakan untuk menentukan volume aktual air yang tertampung pada grid dengan mengkonversi tinggi muka air hasil pembacaan sensor ultrasonik.

\subsection{Uji droplet penyemprotan sprayer}

a. Debit penyemprotan

Debit penyemprotan $(Q$, liter/det) diperoleh dengan mengukur volume semprotan $(V$, liter) yang keluar dari nosel per satuan waktu $(t$, detik) pada tekanan optimum dan dinyatakan dalam satuan liter/menit (BSNI, 2008). Interval waktu penyemprotan sprayer adalah 10 detik. Pengujian dilakukan pada tekanan $300 \pm 20 \mathrm{kPa}$ atau $3 \pm 0,2$ bar (BSNI, 2008). Volume yang keluar dari nosel ditampung dan diukur menggunakan gelas ukur.

b. Sudut penyemprotan, lebar dan tinggi penyemprotan efektif

Pengukuran parameter sudut penyemprotan, lebar dan tinggi peyemprotan efektif mengacu pada SNI 4513.2008 tentang unjuk kerja dan metode uji penyemprotan sprayer. Pengujian dilakukan pada ketinggian nosel 40, 50,60, dan $70 \mathrm{~cm}$. Sudut penyemprotan (Gambar 3) merupakan besar sudut butiran halus yang dibentuk oleh nosel pada tekanan semprot optimum. Lebar penyemprotan efektif $\left(L_{\mathrm{PE}}\right)$ merupakan besar jarak horisontal butiran halus yang dibentuk oleh nosel dimana distribusi volume cairan semprotnya paling seragam, atau koefisien variasi distribusi volume cairan semprotnya minimum, yang disetel pada tekanan semprot optimum (BSNI, 2008).

Pengukuran volume air yang tertampung wadah (grid container) hasil semprotan pada alur patternator konvensional menggunakan water level detector. Pengukuran lebar penyemprotan menggunakan meteran dengan melihat panjang alur patternator konvensional yang mengalirkan air keluaran droplet. Data lebar penyemprotan juga digunakan untuk membentuk grafik tumpang tindih.

Grafik tumpang tindih terdiri dari grafik murni yang didapatkan dari data penyemprotan langsung dan grafik overlapping yang 


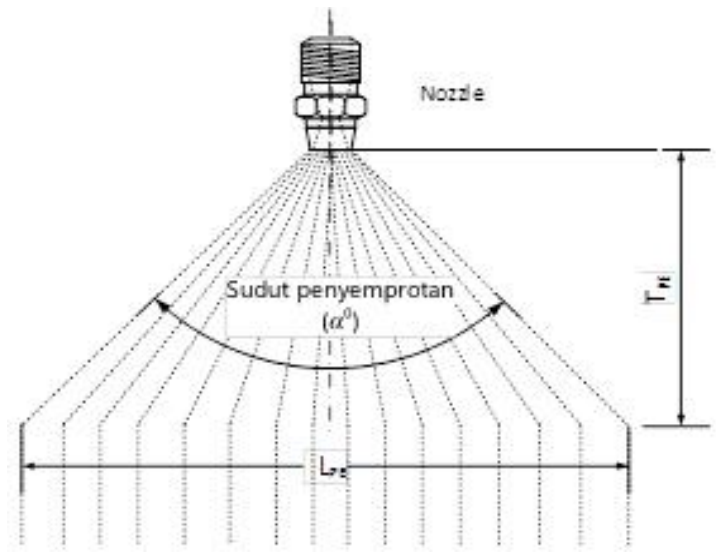

Gambar 3. Sudut Penyemprotan, Lebar dan Tinggi Penyemprotan Efektif

merupakan pergeseran dari grafik murni ke arah kanan dan kiri sehingga terjadi perpotongan dari grafik-grafik tersebut. Grafik tumpang tindih ini digunakan untuk merekomendasikan penggunaan nosel yang lebih dari satu dengan hasil penyemprotan berimbang. Batas volume keluaran sprayer optimal diperoleh dari penjumlahan volume cairan yang masuk dalam kurva overlapping.

Selain itu, nilai sudut penyemprotan dan lebar penyemprotan efektif digunakan untuk penentuan tinggi penyemprotan efektif. Tinggi penyemprotan efektif $\left(T_{\mathrm{PE}}\right.$ ) merupakan besar jarak vertikal butiran halus yang dibentuk oleh nosel, yang diukur dari mulut nosel ke bidang horisontal pada saat terbentuk lebar penyemprotan efektif (BSNI, 2008). Untuk menentukan tinggi penyemprotan efektif dapat menggunakan Persamaan 1.

$$
T_{P E}=\left[\frac{\frac{1}{2} * L_{P E}}{\tan \left(\frac{1}{2} * \alpha\right)}\right]
$$

c. Pengujian pola distribusi penyemprotan sprayer

Pengujian dilakukan dengan ketinggian nosel 40, 50, 60 dan $70 \mathrm{~cm}$ pada Grid Patternator. Droplet yang jatuh dan tertampung pada tiap grid dihitung volumenya kemudian ditabulasi pada tabel kerja.

d. Kecepatan kerja penyemprotan

Perhitungan kecepatan kerja dilakukan dengan mencatat jarak/panjang dan waktu yang dibutuhkan untuk menempuh lintasan kerja ketika sprayer diaplikasikan di lapangan. Tiga track lahan percobaan dengan panjang lintasan 10 meter diterapkan untuk pengukuran ini. Waktu tempuh diukur menggunakan stopwatch lalu nilai dirata-rata. Kecepatan kerja dihitung menggunakan Persamaan 2.

$$
v=\frac{s}{t}
$$

Dimana: $v$ adalah kecepatan kerja (m/det), $s$ adalah jarak lintasan kerja (meter), dan $t$ adalah waktu tempuh (detik).

e. Volume aplikasi penyemprotan

Volume aplikasi alat semprot dihitung menggunakan Persamaan 3.

$$
V=\frac{Q}{L^{*} v}
$$

dimana: $V$ adalah volume aplikasi alat semprotan (L/Ha), $Q$ adalah debit penyemprotan (L/det), $L$ adalah lebar penyemprotan teoritik (m), dan $v$ adalah kecepatan kerja penyemprotan (m/det).

\section{HASIL DAN PEMBAHASAN}

\subsection{Kalibrasi Water Level Detector}

Untuk mengetahui tingkat akurasi dari sensor ultrasonik, kalibrasi sensor HC-SR04 dilakukan dengan pembacaan volume air $\left(\mathrm{V}_{\mathrm{obs}}\right)$ sesuai dengan tinggi air aktual $\left(\mathrm{H}_{\text {act }}\right)$. Persamaan linear hasil kalibrasi (Gambar 4) digunakan sebagai acuan dalam pembacaan volume air pada grid container pada pengujian penyemprotan menggunakan patternator konvensional. Gambar 4 menunjukkan nilai korelasi $\mathrm{R}^{2}=0,9971$ pada kurva linier: $y=2,5721+2,5018 x$, dengan $x$ adalah pembacaan tinggi muka cairan 
(mm) dan y adalah volume cairan dalam wadah (mL). Dari persamaan tersebut, apabila pembacaan tinggi muka cairan berada kurang dari $0,98 \mathrm{~mm}$ maka volume $(y)$ akan bernilai negatif. Pada kondisi ini volume cairan aktual tidak lebih dari 0,019 $\mathrm{mL}$ atau dengan kata lain pembacaan sensor sangat rendah sehingga ditetapkan pada nilai $0 \mathrm{~mm}$.

\subsection{Debit Penyemprotan}

Hasil pengukuran debit penyemprotan sprayer tipe gendong disajikan pada Tabel 1. Debit penyemprotan yang dihasilkan berada pada nilai 0,033 L/det. Faktor yang mempengaruhi debit penyemprotan adalah pengaruh nosel dan tekanan. Jenis nosel mempengaruhi besar droplet yang keluar. Pada penyemprotan sprayer pestisida, pengkabutan (atomizing) cairan merupakan cara paling efektif untuk mendistribusikan pestisida pada permukaan tanaman. Faktor lain adalah tekanan semprot. Perbedaan tekanan tersebut mengakibatkan adanya perbedaan debit, panjang penyemprotan dan luas penyemprotan (Rahman dan Yamin, 2014). Semakin besar tekanan yang diberikan pada pemompaan berpengaruh terhadap terhadap besar cairan yang disemprotkan. Pada keadaan ini berlaku hukum Pascal yang menyatakan bahwa tekanan yang diberikan pada zat cair di dalam ruang tertutup diteruskan oleh zat cair itu ke segala arah dengan sama besar. Tekanan yang sama besar dan melewati penampang (pipa) dengan diameter yang sama menyebabkan laju aliran yang mengalir sama besar sehingga volume cairan yang keluar pada nosel memiliki nilai yang hampir sama (Yuwana, 2014). Debit dipengaruhi oleh kecepatan aliran air, semakin besar kecepatan aliran air maka debit yang dihasilkan semakin besar, dan begitu juga sebaliknya (Muhlizah, 2018).

\subsection{Lebar dan Tinggi Penyemprotan Efektif} Lebar penyemprotan teoritik (Gambar 5) merupakan lebar maksimum yang dapat dijangkau nosel untuk melakukan penyemprotan pada tekanan optimum sprayer. Penyemprotan pada ketinggian nosel 40, 50, 60, dan $70 \mathrm{~cm}$ dilakukan di atas patternator konvensional. Penyemprotan ini dilakukan pada selang waktu 30 detik. Akibat kemiringan $20^{\circ}$, air semprotan yang mengenai patternator akan mengalir ke bawah dan tertampung pada wadah penampung kemudian diukur volume yang tertampung di tiap alur. Lebar penyemprotan teoritik diperoleh dari mengukur panjang aluralur yang mengalirkan air atau tempat penampung yang terisi oleh cairan.

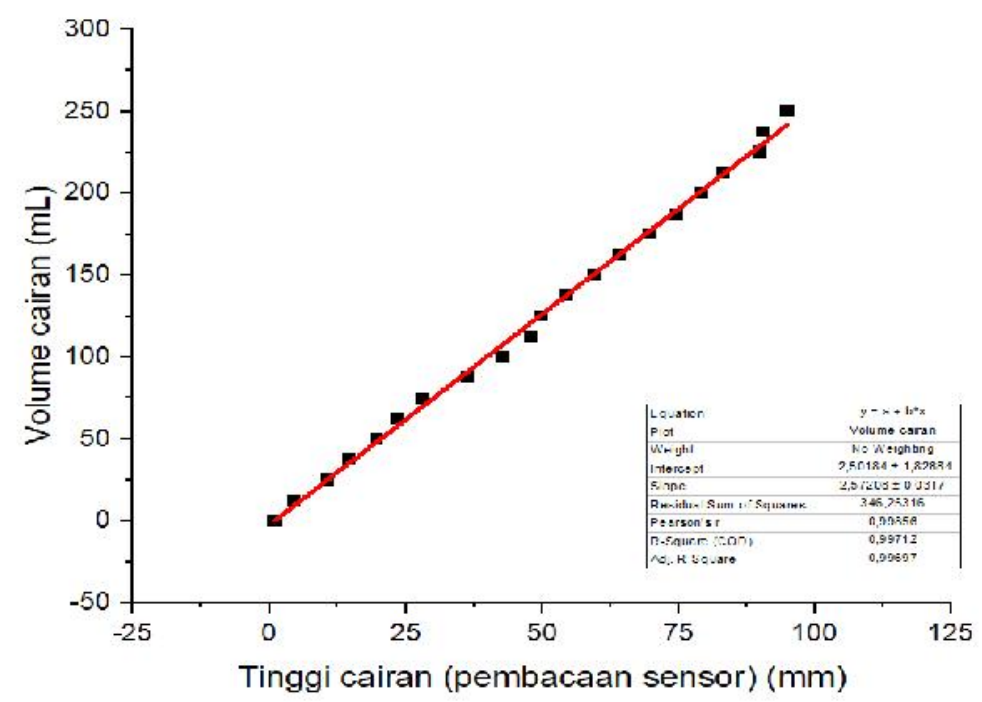

Gambar 4. Kalibrasi Sensor Ultrasonik HC-SR04 untuk Pembacaan Volume Cairan

Tabel 1. Debit Penyemprotan Sprayer

\begin{tabular}{ccccccc}
\hline $\begin{array}{c}\text { Waktu } \\
\text { (detik) }\end{array}$ & \multicolumn{3}{c}{ Volume (mL) } & & $\begin{array}{c}\text { Rata-rata } \\
\text { Volume (L) }\end{array}$ & $\begin{array}{c}\text { Debit } \\
\text { (L/det) }\end{array}$ \\
\hline 10 & 340 & 2 & $\mathbf{3}$ & & 332 & 0,033 \\
\hline
\end{tabular}


Lebar penyemprotan efektif diperoleh dari sebaran air yang paling seragam (Yuwana, 2014). Lebar penyemprotan efektif digambarkan pada grafik tumpang tindih (overlapping) sehingga terjadi perpotongan antara grafik. Penentuan lebar penyemprotan efektif dapat diperoleh dari koefisien variasi (CV). Lebar penyemprotan efektif dipilih dari lebar dengan $\mathrm{CV}$ yang minimum (paling merata) (Yuwana, 2014). Lebar penyemprotan efektif disajikan pada Gambar 6 dimana masing-masing tinggi penyemprotan 40,50, 60 dan $70 \mathrm{~cm}$ memiliki lebar penyemprotan efektif $0,48,0,56$, 0,64 , dan $0,56 \mathrm{~m}$.

Dari Gambar 6 juga diperoleh bahwa tinggi penyemprotan mempengaruhi lebar penyemprotan efektif. Tinggi penyemprotan 60 $\mathrm{cm}$ menghasilkan lebar penyemprotan efektif paling besar 0,64 $\mathrm{m}$. Sedangkan pada ketinggian $70 \mathrm{~cm}$ menunjukkan penurunan lebar penyemprotan efektif $0,56 \mathrm{~m}$. Semakin tinggi nosel, distribusi penyemprotan nosel sangat sensitif dan mudah terusik oleh pergerakan udara. Efisiensi penyemprotan nosel diperolah berturut pada ketinggian semprot 40,50,60, dan $70 \mathrm{~cm}$ masing-masing 54,55\%, 53,85\%, 57,14\%, dan $53,85 \%$.

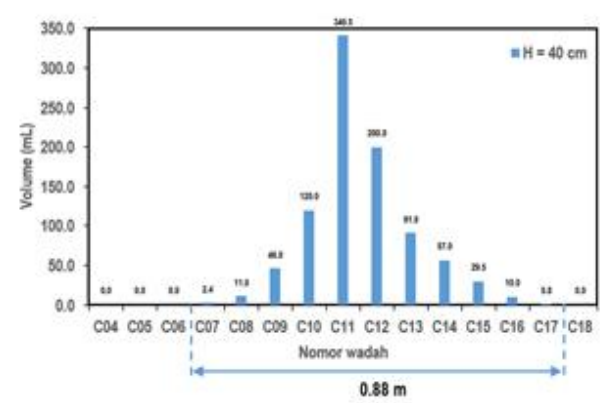

(a)

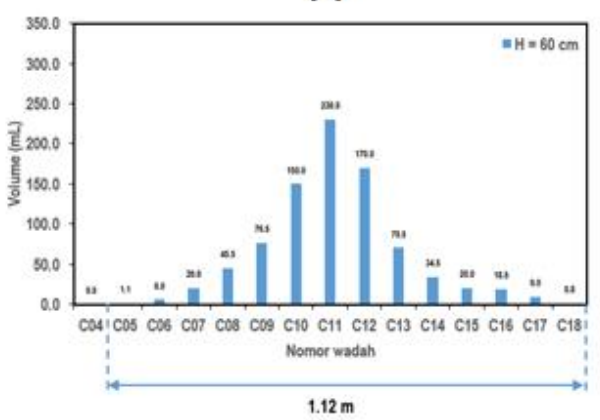

(c)
Perhitungan tinggi penyemprotan efektif dari perlakuan tinggi penyemprotan ditunjukkan pada Tabel 2. Dari perhitungan diperoleh bahwa semakin tinggi penyemprotan maka tinggi penyemprotan efektif yang diperoleh semakin besar. Pada penyemprotan sprayer pestisida di lapangan, tinggi penyemprotan sprayer disesuaikan dengan kondisi tanaman. Semakin dekat jarak nosel pada tanaman maka pemberian cairan pestisida pada permukaan tanaman akan semakin banyak, dan sebaliknya. Selain itu, semakin tinggi penyemprotan sprayer maka droplet mudah terusik oleh pergerakan udara. Pemberian pestisida berlebih berdampak buruk bagi kesehatan manusia, lingkungan dan menyebabkan resistensi hama (Wilis, 2013).

\subsection{Pola dan Luas Distribusi Penyemprotan} Hasil penentukan pola distribusi semprot disajikan pada Gambar 7 dan diketahui bahwa vasiasi ketinggian semprot mempengaruhi lebar variasi dan luas permukaan yang terkena droplet. Semakin tinggi penyemprotan maka semakin luas permukaan yang terkena droplet dan sebaliknya. Jumlah grid yang terkena semprot dari variasi ketinggian semprot $40,50,60$, dan $70 \mathrm{~cm}$ masing-masing adalah $124,198,217$, dan

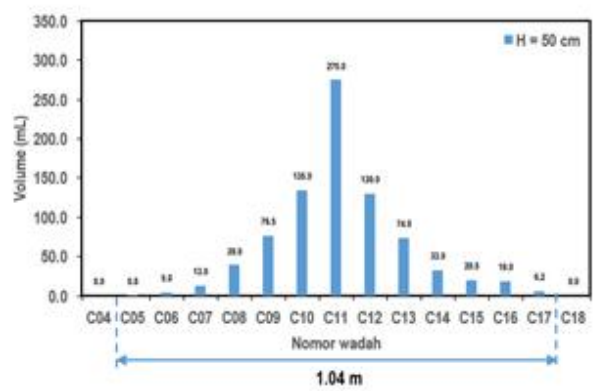

(b)

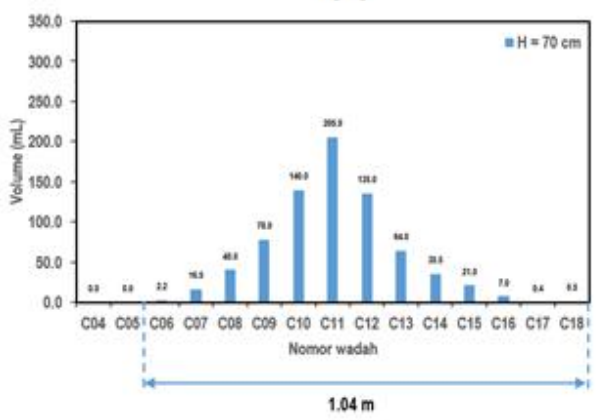

(d)

Gambar 5. Lebar Penyemprotan Sprayer pada Tinggi Semprotan: (a) $40 \mathrm{~cm}$, (b) $50 \mathrm{~cm}$, (c) $60 \mathrm{~cm}$, dan (d) $70 \mathrm{~cm}$ 
Tabel 2. Pengaruh Tinggi Nosel Terhadap Tinggi Penyemprotan Efektif

\begin{tabular}{c|c|c|c|c|c}
\hline $\begin{array}{c}\text { Ketinggian } \\
(\mathbf{H}, \mathbf{c m})\end{array}$ & $\begin{array}{c}\text { Sudut } \\
\text { Semprot }\left(\boldsymbol{\alpha}^{\mathbf{0}}\right)\end{array}$ & $\begin{array}{c}\text { Lebar Teoritik } \\
\left(\mathbf{L}_{\mathbf{P T}}, \mathbf{m}\right)\end{array}$ & $\begin{array}{c}\text { Lebar Efektif } \\
\left(\mathbf{L}_{\mathbf{P E}}, \mathbf{m}\right)\end{array}$ & $\begin{array}{c}\text { Efisiensi } \\
\mathbf{( \% )}\end{array}$ & $\begin{array}{c}\text { Tinggi Efektif } \\
\left(\mathbf{T}_{\mathbf{P E}}, \mathbf{m}\right)\end{array}$ \\
\hline 40 & 95,46 & 0,88 & 0,48 & 54,55 & 0,218 \\
50 & 95,25 & 1,04 & 0,56 & 53,85 & 0,255 \\
60 & 85,90 & 1,12 & 0,64 & 57,14 & 0,344 \\
70 & 57,39 & 1,04 & 0,56 & 53,85 & 0,512 \\
\hline
\end{tabular}

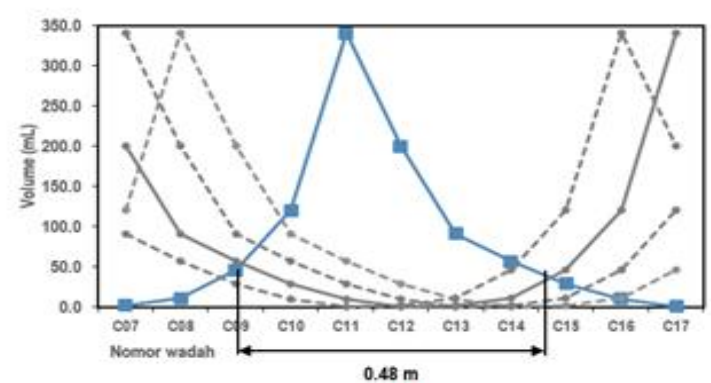

(a)

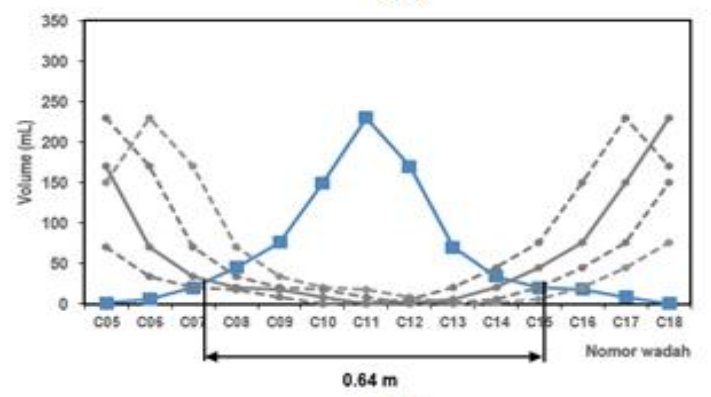

(c)

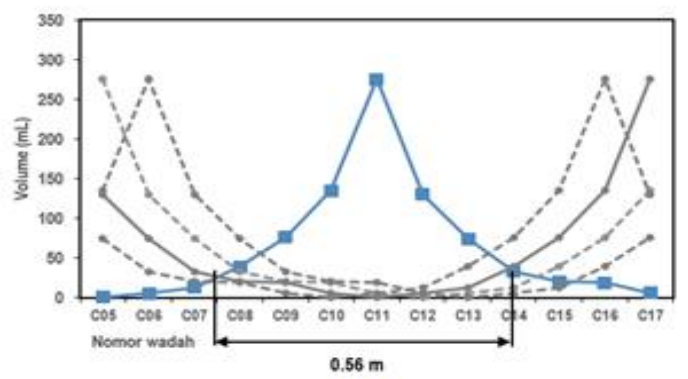

(b)

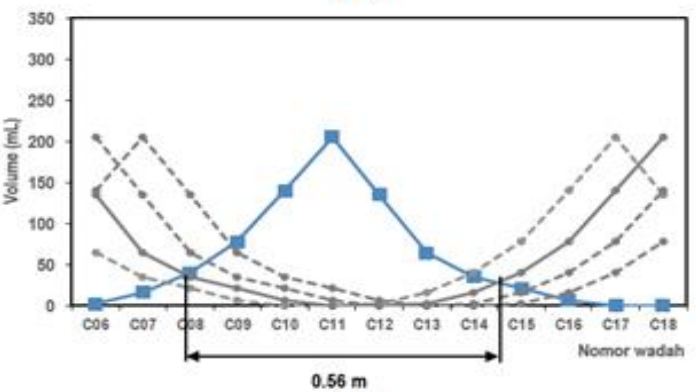

(d)

Gambar 6. Kurva Overlapping pada Tinggi Semprotan: (a) $40 \mathrm{~cm}$, (b) $50 \mathrm{~cm}$, (c) $60 \mathrm{~cm}$, dan (d) 70 $\mathrm{cm}$

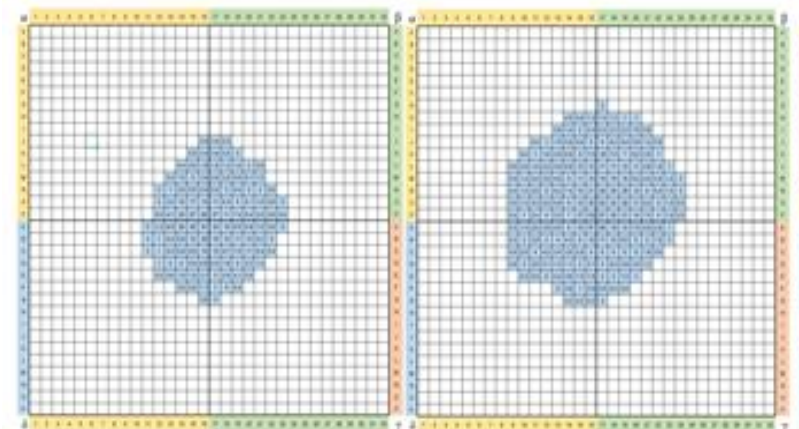

(a) (b)

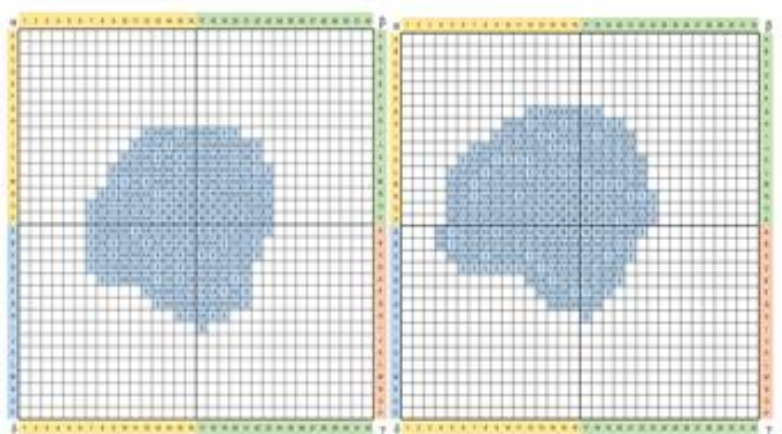

(c) (d)

Gambar 7. Pola Distribusi Penyemprotan Sprayer pada Ketinggian: (a) 40 cm, (b) 50 cm, (c) 60 $\mathrm{cm}$, dan (d) $70 \mathrm{~cm}$

247 dengan luas permukaan yang terkena semprot masing-masing $0,335,0,535,0,587$, dan $0,668 \mathrm{~m}^{2}$.

\subsection{Kecepatan Kerja Penyemprotan}

Hasil pengukuran kecepatan kerja dari keempat perlakuan ketinggian semprot disajikan pada
Gambar 8. Dari pengukuran yang dilakukan, tren kecepatan kerja yang menunjukkan berangsur naik sepanjang bertambahnya ketinggian semprot. Pada ketinggian semprot $40 \mathrm{~cm}$ diperoleh kecepatan kerja $0,29 \mathrm{~m} / \mathrm{s}$, sedangkan pada ketinggian semprot $70 \mathrm{~cm}$ menghasilkan kecepatan kerja 0,57 m/s. Ketinggian semprot 


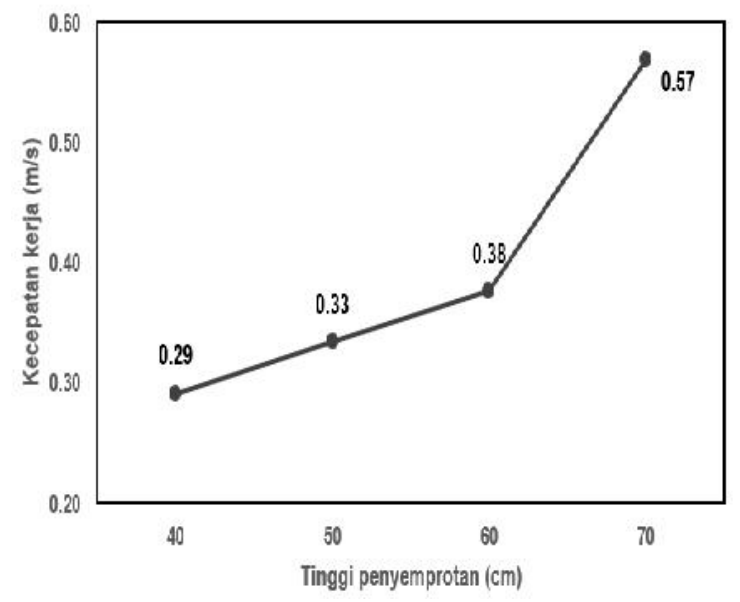

Gambar 8. Kecepatan Kerja Penyemprotan pada Variasi Tinggi Semprotan

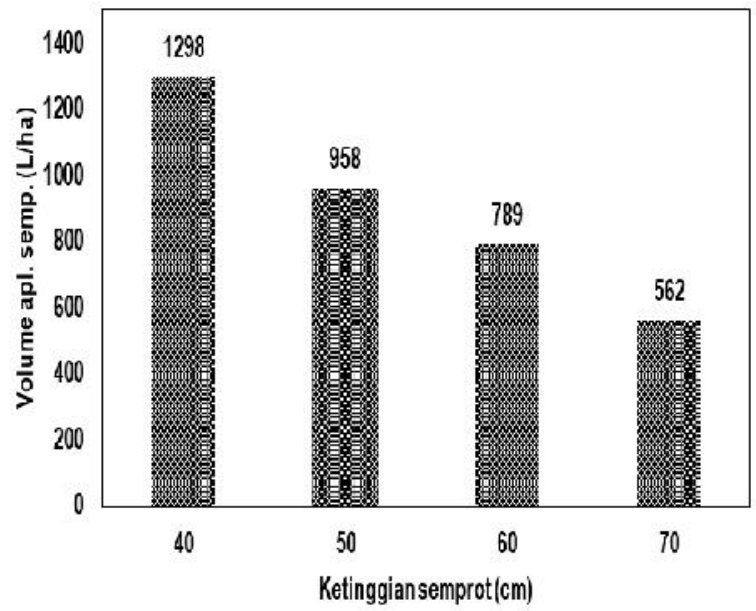

Gambar 9. Volume Aplikasi Penyemprotan pada Variasi Tinggi Semprotan

mempengaruhi luas area tanaman yang terkena semprotan cairan.

\subsection{Volume Aplikasi Penyemprotan}

Perhitungan volume aplikasi penyemprotan digunakan untuk menentukan jumlah cairan yang dibutuhkan untuk melakukan penyemprotan cairan pestisida pada luasan tertentu. Hasil perhitungan volume aplikasi penyemprotan disajikan pada Gambar 9.

Perlakukan ketinggian semprot pada penyemprotan cairan pestisida cenderung memiliki trend menurun. Jumlah aplikasi penyemprotan cairan menggunakan sprayer di lapangan bergantung dari kecepatan operator, jumlah nosel yang digunakan, lebar semprot, dan tekanan yang dipakai (Daywin et al, 1992). Pada penelitian yang dilakukan, sangat penting untuk menjaga kecepatan jalan/kerja yang konstan. Perubahan kecepatan lebih lambat berakibat pada volume cairan yang disemprotkan. Pengaruh ketinggian semprot mempengaruhi lebar penyemprotan. Ketinggian $70 \mathrm{~cm}$ menghasilkan semprotan lebih lebar sehingga permukaan tanaman lebih luas terkena semprotan dan membuat nilai kecepatan kerja juga besar. Berbeda pada penyemprotan dengan ketinggian $40 \mathrm{~cm}$ yang menghasilkan lebar penyemprotan pendek sehingga kecepatan jalan melambat agar permukaan tanaman kerkena cairan. Sedangkan faktor tekanan berpengaruh terhadap volume semprotan cairan. Sangat disarankan pada pengaplikasian sprayer di lapangan dilakukan dengan tekanan konstan.

\section{KESIMPULAN DAN SARAN}

\subsection{Kesimpulan}

Hasil kalibrasi sensor ultasonik menunjukkan bahwa perangkat dapat membaca volume hasil 
penyemprotan pada grid dengan nilai korelasi $\mathrm{R}^{2}=0,99$ pada kurva linier dengan persamaan $y=2,5721+2,5018 x$. Pengujian sprayer menunjukkan debit penyemprotan 0,033 L/det. Penyemprotan optimal sprayer berada pada tinggi semprot $60 \mathrm{~cm}$ dengan lebar penyemprotan efektif $0,64 \mathrm{~m}$ dan tinggi penyemprotan efektif $0,344 \mathrm{~m}$. Pola distribusi penyemprotan yang diukur menggunakan grid patternator menunjukkan bertambahnya tinggi semprot mempengaruhi luas penyemprotan. Kecepatan kerja akibat perbedaan tinggi penyemprotan dari $40 \mathrm{ke} 70 \mathrm{~cm}$ cenderung naik akibat penyemprotan yang dihasilkan lebar dengan nilai kecepatan $0,29 \mathrm{~m} / \mathrm{s}$ dan $0,58 \mathrm{~m} / \mathrm{s}$, sedangkan volume aplikasi penyemprotan menurun pada nilai $1298 \mathrm{~L} /$ ha ke $562 \mathrm{~L} / \mathrm{ha}$.

\subsection{Saran}

Untuk penelitian selanjutnya, diharapkan dapat menggunakan berbagai macam tipe sprayer, variasi tipe nosel yang digunakan, variasi tekanan semprot, dan menggunakan nosel yang lebih dari satu. Selain itu, penelitian lanjutan diharapkan dapat diaplikasikan pada tanaman pertanian yang berbeda, karena pemberian jumlah cairan pestisida berbeda-beda tergantung jenis tanaman.

\section{DAFTAR PUSTAKA}

Andayani, M., Indrasari, W., dan Iswanto, B. H. 2016. Kalibrasi Sensor Ultrasonik HC-SR0 4 sebagai Sensor Pendeteksi Jarak pada Prototipe Sistem Peringatan Dini Bencana Banjir. Prosiding Seminar Nasional Fisika, 5, 43-46.

BSNI. 2008. SNI 4513. 2008: Alat Pemeliharaan Tanaman - Sprayer Gendong Semi Otomatis - Unjuk Kerja dan Metode Uji. Jakarta: Badan Standarisasi Nasional.

Budi, G. P. 2009. Beberapa Aspek Perbaikan Penyemprotan Pestisida untuk Mengendalikan Organisme Pengganggu Tanaman. Agritech, 11(2), 69-80.

Cengel, Y. A., dan Cimbala, J. M. 2018. Fluid Mechanics: Fundamentals and Applications,
Forth Edition. New York: McGraw-Hill Education.

Daywin, F. J., Sitompul, R. G., dan Imam, H. 1992. Mesin-mesin Budidaya Pertanian. Bogor: JICA-DGHE/IPBProject.

Forque, D., Pieters, J. G., dan Nuyytens, D. 2012. No Title. Spray deposition and distribution in a bay laurel crop as affected by nozzle type, air assistance and spray direction when using vertical spray booms. Crop Protections, 41, 77-87.

Guntur, A. P., Igbal, dan Sapsal, A. 2016. Uji Kinerja Knapsack Sprayer Tipe Pb 16 Menggunakan Hollow Cone Nozzle dan Solid Cone Nozzle. Jurnal AgriTechno, 9(2), 107-113.

KEMENTAN. 2016. Statistik Sarana dan Prasarana Pertanian Tahun 2011-2015. Jakarta: Direktorat Jenderal Prasarana dan Sarana Pertanian Kementerian Pertanian RI.

Muhlizah, M. W. 2018. Kinerja Knapsack Power Sprayer dan Mist Blower pada Pengendalian Gulma Lahan Kering Menggunakan Mobile Sprayer Machine. Skripsi. Bogor: Institut Pertanian Bogor.

Permana, A., Triyanto, D., dan Rismawan, T. 2015. Rancang Bangun Sistem Monitoring Volume dan Pengisian Air Menggunakan Sensor Ultrasonik Berbasis Mikrokontroler AVR ATMega8. Jurnal Coding, 3(2), 76-87.

Prabaningrum, L. 2017. Pengaruh Arah Pergerakan Nozzle dalam Penyemprotan PestisidaTerhadap Liputan dan Distribusi Butiran Semprot dan Efikasi Pestisida pada Tanaman Kentang. Jurnal Hortikulture, 27(1), 113-126.

Rahman, M. N., dan Yamin, M. 2014. Modifikasi Nosel pada Sistem Penyemprotan untuk Pengendalian Gulma Menggunakan Sprayer Gendong Elektrik. Jurnal Keteknikan Pertanian, 2(1), 39-46. 
Smith, D. W., Sims, B. G., dan O'Niell, D. H. 1994. Yuwana, N. A. 2014. Desain dan Kontruksi Grid Testing and Evaluation of Agricultural Machinery and Equipment: Principles and Practices. Rome: Food and Agriculture Organization, United Nations.

Sudarmo, S. 1991. Pestisida. Yogyakarta: Kanisius.

Wilis, R. 2013. Peningkatan Penerapan Geografi Pertanian dengan Pembuatan Pestisida Nabati untuk Tanaman Kakao (Theobroma cacao L.) di Kenagarian Kaum Kabupaten Tanah Data. Jurnal Geografi, 2(2), 112-126. Patternator untuk Pengujian Kinerja Penyemprotan Sprayer. Skripsi. Bogor: Institut Pertanian Bogor.

Zhai, C., Zhao, C., Wang, X., Wang, N., Zou, W., dan Li, W. 2015. Two-Dimensional Automatic Measurement for Nozzel Flow Distribution using Improved Ultrasonic Sensor. Sensors, $15,26353-26367$. 